\title{
СУДЕБНОЕ УСМОТРЕНИЕ ПРИ РАССМОТРЕНИИ СЕМЕЙНО-ПРАВОВЫХ СПОРОВ О РАСТОРЖЕНИИ БРАКА
}

\section{JUDICIAL DISCRETION \\ IN THE CONSIDERATION OF FAMILY LAW DISPUTES ON THE DISSOLUTION OF MARRIAGE}

\section{Sokolkina}

Summary. The article deals with the issue of judicial discretion in resolving disputes about the dissolution of marriage. The author gives a definition of judicial discretion, reveals the factors that affect the internal conviction of the judge. The main part outlines in detail the range of disputes during the dissolution of marriage, in the resolution of which the judicial discretion takes part. The conclusion defines the circumstances affecting the place of judicial discretion in family law disputes.

Keywords: judicial discretion, internal persuasion, divorce, mediation, judicial practice.

\author{
Соколкина Марина Александровна \\ Уральский филиал ФГБОУ ВО «Российский \\ государственный университет правосудия», \\ 2. Челябинск \\ drimma7@mail.ru
}

Аннотация. В статье рассматривается вопрос судебного усмотрения при разрешении споров о расторжении брака. Автор дает определение судебного усмотрения, раскрывает факторы, влияющие на внутреннее убеждение судьи. В основной части подробно очерчивается круг споров при расторжении брака, при разрешении которых принимает участие судебное усмотрение. В заключении определяются обстоятельства, влияющие на место судебного усмотрения в семейно-правовых спорах.

Ключевые слова: судебное усмотрение, внутреннее убеждение, расторжение брака, медиация, судебная практика.

лова [15], С.Ж. Соловых [16], М.К. Треушников [17] и др.) полагаем, что в настоящее время в Российской Федерации проблема судейского усмотрения в цивилистическом процессе не получила четкого и полного разрешения на уровне научной доктрины.

Так, П.В. Марков считает, что «судебное усмотрение представляет собой не особое полномочие, предоставленное суду, а способ осуществления властных полномочий по разрешению правовых споров и совершению отдельных процессуальных действий» [14, с. 15].

Иной позиции придерживается К.И. Комиссаров, по мнению которого, «судейское усмотрение - предоставленное суду полномочие по принятию, исходя из конкретных условий, такого решения относительно права, возможность которого исходит из определенных общих и относительных положений закона» [13, с. 51].

А. Барак отмечает, что усмотрение - это полномочие лица, наделенного властью, по осуществлению выбора между двумя и более альтернативами, когда каждая из данных альтернатив является законной [9, с. 299].

Л.Н. Берг под судебным усмотрением подразумевает «элемент судебной правоприменительной деятельности, заключающийся в выборе мотивированного 
законного и обоснованного решения, совершаемого уполномоченным субъектом (судьей) по конкретному юридическому делу в пределах, установленных нормой права» $[10$, с. 61].

Итак, судебное усмотрение имеет свои пределы. Оно допустимо лишь в тех случаях, когда закон допускает свободу судьи в принятии того или иного решения.

Полагаем, что решение вопроса о пределах судебного усмотрения представляется сложным и неоднозначным как с теоретической, так и с практической точек зрения.

Как пишет Л.Н.Берг, пределы судебного усмотрения - «это правовые рамки, установленные управомоченными субъектами с помощью правовых юридических средств, четко ограничивающие объем применения права» [10, с. 62].

В связи с этим, думается, следует привести утверждение А.А. Березина, что суд должен выносить свои решения с учетом принципов законности, справедливости, целесообразности [11, с. 12], а также категорий нравственности, добросовестности и разумности, на что указывает К.П. Ермакова [12, с. 95].

Тогда, взяв за основу определение рассматриваемого явления, сделанное Л.Н. Бергом, считаем целесообразным его дополнить приведенными замечаниями указанных авторов и сформулировать следующим образом в более развернутом виде: «Пределы судебного усмотрения - это правовые рамки, установленные управомоченными субъектами с помощью правовых юридических средств, четко ограничивающие объем применения права с учетом принципов законности, справедливости, целесообразности, а также категорий нравственности, добросовестности и разумности».

Как указывает С.Ж. Соловых, «пределы судебного усмотрения будут в полной мере соответствовать содержанию принципа законности, если суд при вынесении судебного акта строго придерживался норм действующего материального и процессуального права» [16, c. 331].

Исследуя усмотрение, А. Барак замечает, что «ни о каком усмотрении не может идти речи, если выбор должен производиться между законным актом и незаконным» [9, с. 301]. Исходя из этого, выбор, осуществляемый судом, должен проводиться только среди законных вариантов решения.

К.П. Ермакова отмечает, что усмотрение как правомочие суда вытекает из таких положений законодатель- ства, как «суд вправе», «суд может», и подобных формулировок управомочивающего характера [12, с. 96].

Полагаем, что заслуживает поддержки позиция тех авторов, которые раскрывают понятие «судейское усмотрение» через категорию «полномочие». По нашему мнению, проведенный анализ показывает, что судейское усмотрение существует лишь в рамках норм действующего законодательства и, соответственно, представляет собой правомочие лица, наделенного установленной нормами права властью.

К сожалению, содержание понятия «пределы судебного усмотрения» действующим законодательством не раскрывается, является оценочной категорией [8, с. 22], что в практической деятельности может служить источником появления ошибок, как неумышленных, так и совершенных с умыслом, проявления злоупотреблений, «судейского произвола».

Полагаем, что в связи с этим, является целесообразным предложенное выше определение этого явления закрепить законодательно.

Применительно к рассмотрению споров о расторжении брака в судебном порядке судебное усмотрение, основанное на внутреннем убеждении, может проявляться в определении одного из супругов, с кем после расторжения брака будут проживать несовершеннолетние дети, в отложении судебного разбирательства для примирения супругов, в определении размера алиментов и родителя, с которого алименты будут взыскиваться, в проведении раздела имущества супругов, в установлении размера содержания, которое имеющий право на его получение супруг сможет получать от другого супруга.

Частью 2 статьи 22 Семейного кодекса Российской Федерации (далее - «СК РФ») [1] установлено, что при отсутствии согласия одного из супругов на развод суд вправе отложить судебное разбирательство и предоставить срок для примирения супругов в пределах трех месяцев. Следовательно, судебное усмотрение проявляется в данной ситуации при предоставлении или отказа в предоставлении срока для урегулирования семейного конфликта. Обратим внимание на то, что Верховным Судом Российской Федерации [6] расширяются границы судебного усмотрения в данном вопросе. Так, судья по собственному усмотрению управомочен несколько раз откладывать разбирательство по делу для примирения супругов, но с учетом того, что общий срок для примирения не может быть больше трех месяцев. Урегулирование спора о расторжении брака в установленные сроки может осуществляться супругами самостоятельно за счет собственных возможностей либо пу- 
тем проведения процедуры медиации в соответствии со статьей 153.5 ГПК РФ. При этом судья откладывает судебное заседание для проведения медиации не по собственной инициативе, а исключительно по ходатайству сторон. Судебное усмотрение не допускается также при принятии определения об отложении судебного разбирательства для проведения медиации: если стороны просят суд о предоставлении времени для проведения примирительных процедур, отказ в проведении медиации не допускается. Однако в соответствии со статьей 169 ГПК РФ суд вправе сократить двухмесячный срок для проведения медиации, в чем и будет выражаться судебное усмотрение. Также стоит иметь в виду, что судебное усмотрение ограничивается в решении вопроса о сокращении срока для примирения: во-первых, сокращение срока допускается по просьбе сторон, во-вторых, для сокращения такого срока требуется указание в определении мотивов принятия такого решения.

Судебное усмотрение играет важную роль в вопросе определения порядка проживания несовершеннолетних детей после расторжения брака. Если соглашение между супругами о проживании несовершеннолетнего ребенка не достигнуто, то в силу части 3 статьи 65 СК РФ такой вопрос будет разрешаться судом. На усмотрение судьи остается оценка привязанности ребенка к каждому из родителей, их личностных и моральных качеств, их способности всеми средствами удовлетворять потребности ребенка, особенностей занятости каждого из родителей, их текущее семейное положение и пр. По устоявшемуся в обыденном правосознании мнению, разрешение вопроса о проживании ребенка совершается в пользу матери, указание на распространенность данного подхода в судебной практике содержится также в Обзоре практики разрешения судами споров, связанных с воспитанием детей, утвержденном Президиумом Верховного Суда РФ 20 июля 2011 г. Однако такой подход не является обязательным ни с точки зрения семейного законодательства, ни с точки зрения позиции Верховного Суда Российской Федерации. Также стоит учитывать имеющееся ограничение судейского усмотрения в данном вопросе: суд обязан учитывать мнение ребенка, достигшего возраста десяти лет, при разрешении вопроса о проживании последнего с тем или иным родителем.

Установление родителя-плательщика алиментов и определение их размера также решаются на основе судебного усмотрения при недостижении между супругами соглашения. Семейным законодательством установлены общие соотношения суммы алиментов и дохода плательщика в зависимости от количества детей, вместе с тем делается оговорка о том, что по усмотрению суда размер алиментов может быть увеличен или уменьшен. Тем не менее, на судебное усмотрение в данном вопросе должны оказывать влияние такие обстоятельства, как наличие у плательщика алиментов иных иждивенцев, его доход, состояние здоровья, а также состояние здоровья ребенка, в пользу которого производится взыскание алиментов и пр. Неполный перечень таких обстоятельств установлен актом Верховного Суда РФ [7].

При отсутствии между супругами соглашения о разделе общей совместной собственности, такой раздел осуществляется судом. Судебное усмотрение в данном вопросе проявляется в: 1) возможности отступления от начал равенства при разделе общего имущества супругов; 2) возможности признания нажитого в период брака имущества собственностью одного из супругов; 3) возможности отнесения приобретенного в период брака имущества к категории личного имущества супруга. Так, при решении вопроса о неравном распределении долей в общем имущества супругов суд по собственному усмотрению устанавливает неуважительные причины неполучения доходов одним из супругов, а также определяет действия в ущерб интересам семьи, сопряженные с распоряжением общим имуществом. Для признания общего имущества супругов личной собственностью одного супруга суд в соответствии с внутренним убеждением устанавливает фактическое прекращение семейных отношений, выявляет те обстоятельства, которые говорили о фактическом отсутствии семьи. Отнесение общего имущества к категории личного и наоборот осуществляется преимущественно в контексте драгоценностей и предметов роскоши. Поскольку единообразных критериев драгоценностей и предметов роскоши в законодательстве нет, то суд с учетом фактического имущественного положения семьи устанавливает, чем в данной конкретной ситуации является тот или иной предмет: вещью индивидуального пользования - личной собственностью, не подлежащей разделу, или предметом роскоши - общей собственностью, подлежащей разделу при расторжении брака.

Категории бывших супругов, имеющих право на получение алиментов после расторжения брака, в СК РФ установлены. Однако в Кодексе отсутствует не только указание размера алиментов, но и некоторые пропорции в зависимости от дохода, как в случае с алиментами на несовершеннолетних детей. Данное обстоятельство способствует проявлению судейского усмотрения в данном вопросе. Так, согласно статье 91 СК РФ размер алиментов определяется в твердой денежной сумме. Судебное усмотрение заключается в учете судьей в соответствии с внутренним убеждением имущественного и семейного положения плательщика алиментов, а также иных обстоятельств, которые суд посчитает важными. 
В заключении заметим, что определение места судебного усмотрения при рассмотрении споров о расторжении брака зависит как от его соотношения с объективностью и беспристрастностью при оценке обстоятельств дела, так и от интересов иных участников процесса.

\section{ЛИТЕРАТУРА}

1. Семейный кодекс Российской Федерации от 29 декабря 1995 г. №223-Ф3 // Собрание законодательства Российской Федерации от 1 января 1996 г. № 1 ст. 16.

2. Уголовно-процессуальный кодекс Российской Федерации от 18 декабря 2001 г. № 174-Ф3 // Собрание законодательства Российской Федерации от 24 декабря 2001 г. № 52 (часть І) ст. 4921.

3. Арбитражный процессуальный кодекс Российской Федерации от 24 июля 2002 г. № 95-Ф3 // Собрание законодательства Российской Федерации от 29 июля 2002 г. № 30 ст. 3012.

4. Гражданский процессуальный кодекс Российской Федерации от 14 ноября 2002 г. № 138-Ф3 // Собрание законодательства Российской Федерации от 18 ноября 2002 г. № 46 ст. 4532.

5. Кодекс административного судопроизводства Российской Федерации от 8 марта 2015 г. № 21-Ф3 // Собрание законодательства Российской Федерации от 9 марта 2015 г. № 10 ст. 1391.

6. Постановление Пленума Верховного Суда РФ от 05.11.1998 № 15 «0 применении судами законодательства при рассмотрении дел о расторжении брака» [Электронный ресурс]. URL: http://www.consultant.ru/document/cons_doc_LAW_20961/ (Дата обращения: 21.09.2021).

7. Постановление Пленума Верховного Суда РФ от 26.12.2017 № 56 «0 применении судами законодательства при рассмотрении дел, связанных со взысканием алиментов» [Электронный ресурc]. URL: http://www.consultant.ru/document/cons_doc_LAW_286361/ (Дата 0бращения: 21.09.2021).

8. Артебякина Н.А. Судебное усмотрение в гражданском судопроизводстве // Арбитражный и гражданский процесс. 2019. № 3. С. 21-25.

9. Барак А. Судейское усмотрение. М.: НОРМА, 2009. 376 с.

10. Берг Л.Н. Судебное усмотрение и его пределы (общетеоретический аспект): дис. ... канд. юрид. наук / Л.Н. Берг. Екатеринбург, 2008. 202 с.

11. Березин А.А. Пределы правоприменительного усмотрения: автореф. дис. ... канд. юрид. наук / А.А. Березин. Нижний Новгород, 2007. 25 с.

12. Ермакова К.П. Понятие и субъективные пределы судебного усмотрения / К.П. Ермакова // Журнал российского права. 2009 . № 8 (152). С. $91-98$.

13. Комиссаров К.И. Судебное усмотрение в советском гражданском процессе // Советское государство и право. 1969. № 4. С. 51-57.

14. Марков П.В. Правовая природа и условия осуществления судебного усмотрения: автореф. дис. ... канд. юрид. наук. М., 2012.24 с.

15. Погорелова Н.С. Судейское усмотрение в производстве по делам об административных правонарушениях: автореф. дис. ... канд. юрид. наук. Ростов H/Д, 2008. 23 C.

16. Соловых С.Ж. Законность судейского усмотрения // Право и его реализация в XXI веке: Сб. науч. тр. В 2 ч. / Под общ. ред. С.Н. Туманова. Саратов: Издво ФГБОУ ВПО СГЮА, 2011. Ч. 1. С. 331-337.

17. Треушников М.К. Арбитражный процесс: учебник для ВУЗов. М.: Городец, 2012. 672 с.

( С Соколкина Марина Александровна (drimma7@mail.ru ).

Журнал «Современная наука: актуальные проблемы теории и практики» 